\title{
Review of Engineering Models of the Lightning Return Stroke and their Application to Lightning Electromagnetic Pulse Calculations
}

\author{
Yoshihiro Baba Member (Doshisha University, ybaba@mail.doshisha.ac.jp)
}

Keywords: lightning return stroke, engineering modeling, lightning electromagnetic pulse (LEMP)

In this technical note, recently proposed engineering models of the lightning return stroke and their application to lightning electromagnetic pulse (LEMP) calculations are reviewed and evaluated. Generally in engineering return stroke models, a current at an arbitrary height along the lightning channel and at an arbitrary time is represented as a simple function of height, time, the return stroke wavefront propagation speed, and the channel base current.

In Section 2, the transmission line (TL) model and the traveling current source (TCS) model, which have been used most frequently out of engineering models of the lightning return stroke attached to flat ground, are reviewed. Also, two models proposed recently are described. The TL model is often visualized by a vertical lossless uniform transmission line excited at its bottom by a lumped current source (actually a vertical conductor cannot be represented by a uniform transmission line). The TCS model is visualized by a vertical lossless uniform transmission line terminated in a lumped matching impedance at its bottom, along which a lumped current source progresses upward at the return stroke wavefront speed. The upward progressing current source injects a current wave only downward into the channel. These two models cannot reproduce all of five features observed in typical measured LEMP waveforms at different distances from a lightning channel. Two new models can reproduce all of them. In the new models, a current wave suffers significant attenuation within the bottom several hundreds of meters, and still suffers not a little attenuation above two kilometers or so along the channel.

In Section 3, two models for the lightning return stroke attached to a tall grounded object are reviewed. One is the distributed shunt current source model, and the other is the lumped series voltage source model. In the former model, each of the distributed shunt current sources located along the transmission line representing a channel is activated when the upward progressing return stroke wavefront arrives there, and the resultant current wave propagates downward at the speed of light. The downward propagating current waves are reflected and/or transmitted at the junction between the transmission lines representing the lightning channel and a tall strike object. In the latter model, transmission lines representing the lightning channel and a tall strike object are excited by a lumped series voltage source inserted between them. This lumped voltage source generates a wave given by $Z_{c h} I_{s c}$, where $Z_{c h}$ is the equivalent impedance of the lightning return stroke channel and $I_{s c}$ is the lightning short circuit current defined as the lightning current that would be measured at a well grounded object of negligible height. The presence of this source does not disturb any transient process within the strike object because its internal impedance is zero.

In Section 4, expressions for calculating electric and magnetic fields radiated from a lightning return stroke channel (and a tall strike object if present), from the current distribution along the lightning channel given by an engineering return stroke model, are reviewed. Here, three different expressions for electric field are shown. The first one is a most widely used expression that was derived using Lorentz condition. The second one is an expression that was derived recently using the continuity equation. The last one is an expression valid only in the restricted condition that the return stroke wavefront speed is equal to the speed of light and a return stroke current wave propagates without attenuation or dispersion. Both of the first and second expressions yield the identical waveform in terms of the total electric field, although each of the three components in the first expression gives a waveform different from that the corresponding component in the second expression gives. The last expression, having only one term that is inversely proportional to the distance from the channel base, yields the same waveform as the other two expressions give in the restricted condition stated above.

In Section 5, new findings obtained from electromagnetic calculations using the engineering models for the lightning return stroke attached to a tall grounded object are shown. For example, the vertical electric field in the vicinity of a tall strike object is reduced significantly by the presence of the tall strike object, while remote electric and magnetic fields are enhanced by it. 


\title{
帰還雷撃の工学モデルと雷電磁界パルス計算への応用
}

\author{
正 員 馬場 吉弘* \\ Review of Engineering Models of the Lightning Return Stroke and their Application to \\ Lightning Electromagnetic Pulse Calculations \\ Yoshihiro Baba*, Member
}

\begin{abstract}
In this technical note, recently proposed engineering models of the lightning return stroke and their application to lightning electromagnetic pulse calculations are reviewed and evaluated. In Section 2, the transmission line model and the traveling current source model, which have been used most frequently out of engineering models of the lightning return stroke attached to flat ground, are described. Then, two models, which have been proposed recently and can reproduce all of five features observed in typical measured lightning electromagnetic field waveforms at different distances from a lightning channel, are explained. In Section 3, two models for the lightning return stroke attached to a tall grounded object are reviewed. One is the distributed shunt current source model, and the other is the lumped series voltage source model. In Section 4, expressions for calculating electric and magnetic fields radiated from a lightning return stroke channel (and a tall strike object if present), from the current distribution along the lightning channel given by an engineering return stroke model, are shown. Three different expressions for electric field are shown here. The first one is a most widely used expression derived using Lorentz condition, the second one is an expression derived recently using the continuity equation, and the last one is an expression valid only in the restricted condition that the return stroke wavefront speed is equal to the speed of light and a return stroke current wave propagates without attenuation or dispersion. In Section 5, new findings obtained from electromagnetic calculations using the engineering models for the lightning return stroke attached to a tall object are shown. For example, the vertical electric field in the vicinity of a tall strike object is reduced significantly by the presence of the tall object, while remote electric and magnetic fields are enhanced by it.
\end{abstract}

キーワード : 㷌還雷撃, 工学的モデリング, 雷電磁界パルス

Keywords: lightning return stroke, engineering modeling, lightning electromagnetic pulse (LEMP)

\section{1. 緒言}

帰還雷撃の工学モデル(1)(2) は, 帰還雷撃路上の雷電流の 時間空間分布を, 高さ, 時間, 帰還雷撃波の伝搬速度等を 変数とする簡単な数式で表現するモデルである。このよう な数式で表現される電流分布を等価回路により実現できる ものもあるが, 通常は工学モデルが示す電流分布とそれに 対応する等価回路やその定数との厳密な関係に注意が払わ れることはない。むしろ, 電流波の減衰, 変わい, 帰還雷 撃波の伝搬速度等の值を, 回路定数や周囲媒質と直接関連 させずに自由に設定できることが工学モデルの利点である といえる。

帰還雷撃のモデルとしては, 工学モデルの他に物理モデ

\footnotetext{
$*$ 同志社大学

干 610-0321 京田辺市多々羅都谷 1-3

Doshisha University

1-3, Miyakodani, Tatara, Kyotanabe, Kyoto 610-0321
}

ル (3), 電磁界モデル (4) および分布定数回路モデル ${ }^{(5)}$ が存在 する (2)。物理モデルは, 帰還雷撃路（の一部）をプラズマ 柱として表現するモデルである。これまでのところ，この 種のモデルが雷電磁界パルス計算に用いられた実績はない。 電磁界モデルは, 帰還雷撃路を細線アンテナとして表現す るモデルであり, 帰還雷撃路上の電流分布はマクスウェル 方程式の数值解として与えられる。最近は工学モデルと並 び頻繁に雷電磁界パルス計算に用いられている(6)(7)。分布定 数回路モデルは, 帰還雷撃路を分布定数回路で表現するモデ ルである。工学モデルや電磁界モデルに比べてモデル数が 少なく, また雷電磁界パルス計算に利用された例も少ない。

上述したように帰還雷撃の工学モデルは, 回路定数や周 囲媒質と直接関連させずに電流波の減衰, 変わい, 帰還雷 撃波の伝搬速度等の值を自由に設定できるという簡便さか ら, 架空配電線や通信線の誘導雷サージ計算等 ${ }^{(8) \sim(1)}$ の雷電 磁界パルス計算に広く利用されている。約 10 年前に, それ までに提案された帰還雷撃モデルとそれらの特徴や性能に 
ついて評価したレビュー論文 (2) が出版されているが，それ 以降にも帰還雷撃の工学モデルやそれを用いた雷電磁界パ ルス計算に関する重要な成果が多数報告されている。

本資料では，国内ではあまり知られていないと思われる 帰還雷撃の工学モデルと同モデルを用いた雷電磁界パルス 計算についての最近の研究動向および研究成果を整理し, 紹介する。第 2 章では, 平坦大地への帰還雷撃の工学モデ ルとして頻繁に用いられているTL（Transmission Line）モ デル (12) と TCS (Traveling Current Source) モデル (13) につ いて説明する。これらのモデルでは, 雷電磁界パルスの測 定波形の特徵のいくつかを再現することができないが，そ れらの全てを再現することに成功した新モデル(14) について も述べる。第 3 章では，最近提案された高構造物を含む帰 還雷撃の 2 つの学モデル ${ }^{(15)(16)}$ について論じる。第 4 章で は，工学モデルによって与えられる電流の時間空間分布を 基に，そこから放射される磁界および電界を計算するため の式（電流と磁界，電界の関係式）を示す。電界計算式と しては，ローレンツ条件を用いて導出され古くから用いら れている式 (12) と電荷連続条件を用いて最近導出された式 ${ }^{(17)}$ を示す。また，帰還雷撃波の伝搬速度が光速で，電流波が 減衰および变わいしない場合の磁界，電界計算式 ${ }^{(18)}$ (それ ぞれ単一の項で表される）も示す。第 5 章では, 高構造物 を含む帰還雷撃の工学モデルを用いた計算により明らかに された雷電磁界パルスが高構造物の存在により受ける種々 の影響 ${ }^{(19) \sim(22)} に$ にいて述べる。

\section{2. 平坦大地への帰還雷撃モデル}

〈2・1〉 平坦大地への帰還雷撃モデリング＼cjkstart平坦大地へ の帰還雷撃の工学モデルの多くは次式で表すことができる。

$$
I\left(z^{\prime}, t\right)=u\left(t-z^{\prime} / v_{f}\right) P\left(z^{\prime}, t\right) I\left(0, t-z^{\prime} / v\right) \cdots \cdots
$$

ここで, $I\left(z^{\prime}, t\right)$ は帰還雷撃路上における任意の高 さ $z^{\prime}$, 任意の時間 $t$ での電流值, $I(0, t)$ は帰還雷撃 路根元部 $\left(z^{\prime}=0\right)$ における任意の時間 $t$ での電流 值, $u(t)$ はへビサイド関数, $P\left(z^{\prime}, t\right)$ は電流の減衰 (変わい) 係数, $v_{f}$ は帰還雷撃波の伝搬速度, $v$ は 帰還雷撃路上における電流波の伝搬速度である。

〈2・2〉 TL モデル 工学モデルの中で最頻繁に用い られている $\mathrm{TL}$ モデル ${ }^{(12)}$ では, $P\left(z^{\prime}, t\right)=1, v_{f}=v$ (帰還 雷撃伝搬速度と電流波伝搬速度が同じ）であり，次式で表 される。

$$
I_{T L}\left(z^{\prime}, t\right)=I\left(0, t-z^{\prime} / v\right)
$$

これは図 1(a)に示すように，特性インピーダンスが一定で 無損失の伝送線路 (Transmission Line) 上を電流波が伝搬す る場合の式と等価である。このことがTL モデルと呼ばれる 理由である。このモデルを用いて計算した帰還雷撃路上の 電流波形を図 2 に示す。帰還雷撃路根元部の電流波形 $I(0, t)$ としては, 後続㴆還雷撃の典型的な電流波形を模擬している

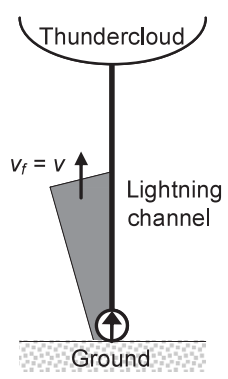

(a) TL model

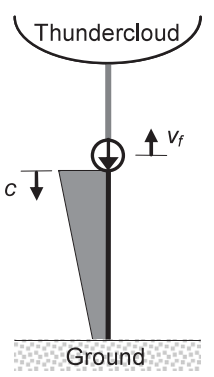

(b) TCS model
図 1 TL モデル ${ }^{(12)}$ と TCS モデル ${ }^{(13)}$ の概念図

Fig. 1. Conceptual illustrations for (a) the TL model and (b) the TCS model.

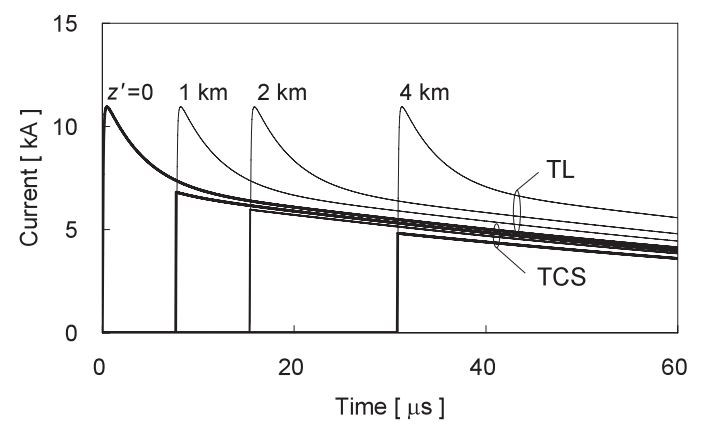

図 2 TL モデル ${ }^{(12)}$ および TCS モデル (13) を用いて 計算した帰還雷撃路上の電流波形

Fig. 2. Waveforms of current at different heights along a lightning return stroke channel calculated using TL and TCS models.

と考えられている波形(1) を用いた。また, $v_{f}=v=130 \mathrm{~m} / \mu \mathrm{s}$ とした。なお，負極性帰還雷撃の光学観測結果により，帰 還雷撃波の平均進行速度は $100 \sim 150 \mathrm{~m} / \mu \mathrm{s}$ 程度 ${ }^{(23)}$ であるこ とが示されている。

実際には完全導体であっても，逆円錐形状以外の垂直導 体上を大地面から上向きに伝搬する電流波は減衰および变 わいすることが知られている ${ }^{(24)}$ 。また，帰還雷撃の光学観 測により，光出力のピーク值は雷撃路の上部にいくほど小 さくなり，その立ち上がり時間が長くなることが示されて いる ${ }^{(25)}$ 。なお，ロケット誘雷実験における地上付近での雷 電流波形と光出力波形の同時観測結果 ${ }^{(26)}$ により，ピーク值 に至るまでは雷電流と光出力の間に比例関係があることが 明らかにされている。

MTLL モデル (Modified TL model with Linear current decay) (27) は電流波の減衰を考慮したモデルであり, MTLD モデル (Modified TL model with current Distortion) ${ }^{(28)}$ は減 衰と変わいの両方を考慮したモデルである。MTLD モデル では, $P\left(z^{\prime}, t\right)=\left[1-\exp \left\{-\left(t-z^{\prime} / v_{f}\right) / \tau \times\left(\lambda_{p} / z^{\prime}\right)\right\}\right]\left(1-z^{\prime} / H\right)$, $v_{f}=v$ であり，次式で表される。

$$
\begin{aligned}
I_{M T L D}\left(z^{\prime}, t\right)= & {\left[1-\exp \left(-\frac{t-z^{\prime} / v_{f}}{\tau} \frac{\lambda_{p}}{z^{\prime}}\right)\right] } \\
& \times\left(1-\frac{z^{\prime}}{H}\right) I\left(0, t-\frac{z^{\prime}}{v}\right) \cdots
\end{aligned}
$$


このモデルでは, 伝搬に伴う電流波の立ち上がり時間の増加 とピーク值の減少をほほ独立に設定できる。文献 (28) では, $\tau=0.3 \mu \mathrm{s}, \lambda_{p}=1000 \mathrm{~m}, H=9000 \mathrm{~m}, v_{f}=v=130 \mathrm{~m} / \mu \mathrm{s}$ という值が用いられている。

〈2·3〉TCS モデルＴCS モデル ${ }^{(13)}$ は，前節で述べ たTL モデルに次いで頻繁に用いられている工学モデルで ある。このモデルでは, 図 1(b) に示すように, 特殊な集中 電流源が帰還雷撃速度 $v_{f}$ で上向きに進行し，その進行する 電流源から下向きに光速 $c$ で伝搬する電流波が出力される。 ただし， $v_{f}<c$ であっても，この集中電流源からは上向きに 電流波が出力されることはなく，TCS モデルが図 1(b) の概 念図と完全に対応しているわけではない。また，下向きに 伝搬する電流波の大地面 $\left(z^{\prime}=0\right)$ での反射は零と仮定され ている(整合条件)。このモデルでは, $P\left(z^{\prime}, t\right)=1, v=-c$ (電流波が光速で下向きに伝搬) であり，次式で表される。

$$
I_{T C S}\left(z^{\prime}, t\right)=u\left(t-z^{\prime} / v_{f}\right) I\left(0, t+z^{\prime} / c\right)
$$

このモデルを用いて計算した帰還雷撃路上の電流波形を図 2 に示す。(4) 式からも明らかなように, 帰還雷撃波が高さ $z^{\prime}$ に到達した瞬間 $\left(t=z^{\prime} / v_{f}\right)$ におけるその部分の電流值は $I_{T C S}\left(z^{\prime}, t=z^{\prime} / v_{f}\right)=I\left(0, z^{\prime} / v_{f}+z^{\prime} / c\right) \neq 0$ となるため, 波 頭部は不連続となる。また，これと同じ理由で，電流波の 伝搬に伴う減衰は考慮していないが，電流のピーク值は， $z^{\prime}>\left(v_{f}+c\right) T_{r}$ (ただし $T_{r}$ は根元部電流の立ち上がり時間 $)$ において高さとともに減少する。

TCS モデルが有する波頭部の電流不連続を修正したモデ ルとして DU (Diendorfer and Uman) モデル ${ }^{(29)}$ が存在す る。DUモデルは，(1)式のみでは表現できず，次式で表さ れる。

$$
\begin{aligned}
I_{D U}\left(z^{\prime}, t\right)= & u\left(t-z^{\prime} / v_{f}\right) I\left(0, t+z^{\prime} / c\right) \\
& -u\left(t-z^{\prime} / v_{f}\right) I\left(0, z^{\prime} / v_{f}+z^{\prime} / c\right) \\
& \times \exp \left[-\left(t-z^{\prime} / v_{f}\right) / \tau_{D}\right] \ldots \ldots \cdots
\end{aligned}
$$

上式の右辺第 1 項目は TCS モデルと同一であり，第 2 項 目が修正項とみなすことができる（ $\tau_{D}$ は放電時定数 $)$ 。第 2 項目の追加により, $I_{D U}\left(z^{\prime}, t=z^{\prime} / v_{f}\right)=0$ となる。

$\langle\mathbf{2} \cdot \mathbf{4}\rangle$ 新モデル 帰還雷撃電流波形は雷撃路の下端 以外においては直接測定することができない。このため, 帰還雷撃モデルが与える電流の時間空間分布の妥当性は, 実際の帰還雷撃に起因した電磁界パルスの多地点での測定 波形の特徴を再現できるか否かによって検証されることが 多い。これらの特徴 ${ }^{(2)}$ を以下に列挙する (図 3 参照)。

(a) 雷撃点から数 $10 \mathrm{~m}$ から $100 \mathrm{~m}$ 程度の範囲内におけ る垂直電界は，立ち上がり後平坦な特性を示す。

(b) 雷撃点から $1 \mathrm{~km}$ 程度以上離れた地点では, 垂直電 界，水平磁界ともに初期に鋭いピークを示す。

(c) 雷撃点から数 $\mathrm{km}$ 程度離れた地点における垂直電界 は，初期ピークの後 $100 \mu \mathrm{s}$ 程度の間，緩やかに上昇を続 ける。
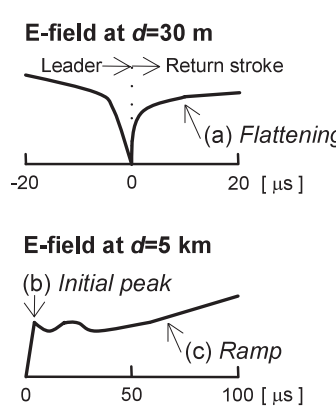

$\mathrm{H}$-field at $\boldsymbol{d}=\mathbf{5} \mathbf{~ k m}$

(b) Initial peak

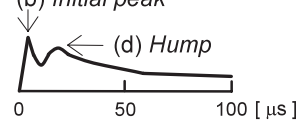

E-field at $\boldsymbol{d}=\mathbf{5 0} \mathbf{~ k m}$ (b) Initial peak

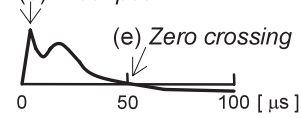

$\mathrm{H}$-field at $d=50 \mathrm{~km}$

(b) Initial peak

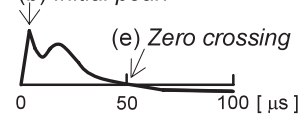

図 3 帰還雷撃（ $a$ のみロケット誘雷実験で得られた 電界測定波形の特徴）に起因した典型的な 電磁界パルス波形の特徵

Fig. 3. Features found in typical measured vertical electric and azimuthal magnetic field waveforms associated with first and subsequent return strokes.

(d) 雷撃点から数 $\mathrm{km}$ 程度離れた地点における水平磁界 は，初期ピークの後にコブ状のピークを示す。

(e) 雷撃点から $50 \mathrm{~km}$ から $200 \mathrm{~km}$ 程度の範囲内におけ る垂直電界, 水平磁界は, 初期ピークの後数 $10 \mu \mathrm{s}$ に極性 が反転する。

〈2・2〉節で述べた TL モデルは, 上記の特徽 (a), (c) およ び (e) を再現することができない。電流波の減衰を考慮し た MTLL モデルおよび減衰と変わいを考慮した MTLD モ デル (パラメータ $\tau=0.3 \mu \mathrm{s}, \lambda_{p}=1000 \mathrm{~m}, H=9000 \mathrm{~m}$, $v_{f}=v=130 \mathrm{~m} / \mu \mathrm{s}$ を使用時) は, 特徽 (d) を再現することが できない。また，〈2·3〉節で述べた TCS モデルおよび DU モデルは，特徵 (e) を再現することができない。

上記の 5 つの特徴の全てを再現できる工学モデルは事実 上存在しなかったが, 最近になって, それらの全てを再現で きる 2 つモデル (14) が提案された。一方は, パラメータ $\lambda_{p}$ として $1000 \mathrm{~m}$ ではなく $50 \mathrm{~m}$ を用いた MTLD モデル [(3) 式である（MTLD2 モデル）。 $\lambda_{p}$ は立ち上がり時間の増加 を決めるパラメータで，これを小さくすればするほど伝搬 に伴う立ち上がり時間の増加が大きくなる。 $\lambda_{p}=50 \mathrm{~m}$ と 極端に小さい值に設定することによって, 図 2 に示した TL モデルを用いた電流計算波形の波頭部分を削り，雷撃路下 端付近での急激な減衰を実現している。他方は, 帰還雷撃 路上部での減衰が比較的緩やかになる DU モデル [(5) 式。 波尾部分は図 2 の TCS モデルを用いた電流計算波形とほぼ 同じ]に，上部で減衰が大きくなる係数を付加したモデルで ある（MDUD モデル : Modified DU model with additional Decay)。同モデルを次式に示す。

$$
I_{M D U D}\left(z^{\prime}, t\right)=I_{D U}\left(z^{\prime}, t\right)\left[1-\exp \left\{-\left(\lambda_{d} / z^{\prime}\right)^{n}\right\}\right]
$$

モデルパラメータの值としては, $\lambda_{d}=5000 \mathrm{~m}, n=2$ が用 
いられている。MTLD2 および MDUD モデルにより計算 した帰還雷撃路上の電流波形を図 4 に示す。両モデルにお いて，電流波は，帰還雷撃路の下端数 $100 \mathrm{~m}$ の範囲で急激 に減衰し，上部においても比較的大きな減衰を続ける。こ のことから，実際の帰還雷撃路上の電流分布も，図 4 に示 された分布に近いと考えられる。

$\langle\mathbf{2} \cdot \mathbf{5}\rangle$ 分布並列電流源を用いた等価表現 (1) 式で表 現される任意の電流分布は，図 5 に模式的に示す分布並 列電流源によっても等価的に表現できることが示されてい る(30)(31)。

図 5 の任意の高さ $z^{\prime}$ における並列電流源は, 帰還雷撃 波が $z^{\prime}$ に到達した時点 $\left(=z^{\prime} / v_{f}\right)$ でターンオンし，電流波 $d I\left(z^{\prime}, t\right)$ を出力する。この電流波は下向きに光速 $c$ で伝搬 し，また大地面に到達しても反射は生じないものと仮定さ れている。時刻 $t$ における帰還雷撃路上の任意の高さ $z^{\prime}$ に おける全電流 $I\left(z^{\prime}, t\right)$ は, $z^{\prime}$ から $H=\left(t+z^{\prime} / c\right) /\left(1 / v_{f}+1 / c\right)$ （時刻 $t$ における $z^{\prime}$ から見た帰還雷撃波頭部の高さ）まで の $d I$ の積分值として次式で与えられる。

$$
I\left(z^{\prime}, t\right)=\int_{z^{\prime}}^{H} d I\left(z, t-\frac{z-z^{\prime}}{c}\right) .
$$

このことは，任意の工学モデルあるいは (1) 式により与 えられる電流分布を実現する (7) 式の解 $\left[d I\left(z^{\prime}, t\right)\right]$ が数学 的に必ず存在することを示している。なお，電気回路とし

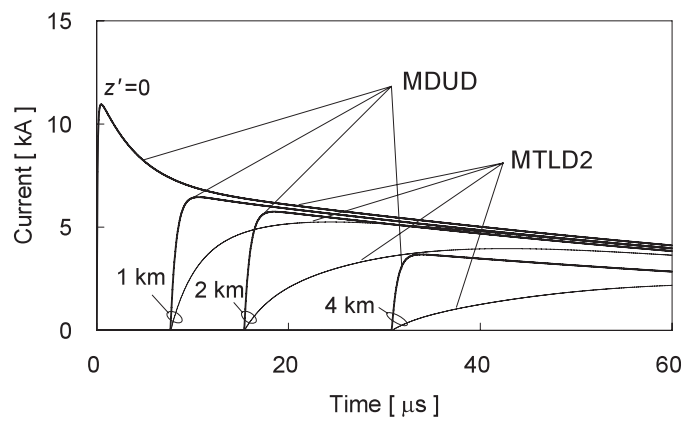

図 4 MTLD2 モデル ${ }^{(14)}$ および MDUD モデル (14) を用いて計算した帰還雷撃路上の電流波形

Fig. 4. Waveforms of current at different heights along a lightning return-stroke channel calculated using MTLD2 and MDUD models.

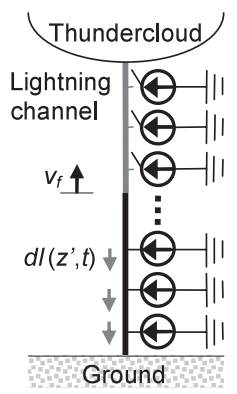

図 5 平坦大地への帰還雷撃の分布並列電流源を 用いた等価表現（下端での反射係数は 0 と仮定） Fig. 5. Equivalent representation of a lightning return stroke attached to flat ground using distributed shunt current sources.
て図 5 を眺めると, 分布並列電流源がターンオンした後は, 電流波は接続点から上下に分流すると考えられるが，下向 きにのみ流れると仮定されており，(7) 式と図 5 の概念図が 完全に対応しているわけではない。

\section{3. 高構造物への帰還雷撃モデル}

$\langle\mathbf{3} \cdot \mathbf{1}\rangle \quad$ 高構造物雷撃のモデリング＼cjkstart雷撃を受けやす い高構造物においては, 雷電流の直接測定が可能であるた め, 落雷位置標定システムの雷電流推定式 (測定磁界一雷電 流変換式）の試験や校正に用いられている ${ }^{(32)(33)}$ 。このよう な試験や校正の妥当性を検証するためには, 高構造物を含 んだ州還雷撃モデルが不可欠である。

帰還雷撃路の等価インピーダンスは $0.6 \sim 2.5 \mathrm{k} \Omega$ 程度 ${ }^{\left({ }^{(3)}\right)}$, テレビ放送塔のような独立構造物の特性インピーダンスは $200 \Omega$ 程度 [例えば高さ $553 \mathrm{~m}$, 根元部半径 $33 \mathrm{~m}$ の CN 夕 ワーを双対円錐アンテナの一方の円錐導体と近似して特性 インピーダンス ${ }^{(35)}$ を求めると $\left.210 \Omega \approx 60 \ln (2 \times 553 / 33)\right]$, 高構造物の接地インピーダンスは，それより一桁程度低い 值と考えられる。このため高構造を含む帰還雷撃モデルで は, 平坦大地への雷撃の場合と異なり, 帰還雷撃路と高構 造物および高構造物と大地との接続点での電流波の反射, 透過を適切に扱える必要がある。

以下では，高構造物を含む帰還雷撃の工学モデルとして 代表的な分布並列電流源モデル(15) と集中直列電圧源モデ ル(16)を紹介する。

〈3・2〉分布並列電流源モデル 図 5 に示した帰還雷撃 の分布並列電流源モデルを応用して高構造物雷撃を図 6(a) のように模擬し, 高構造物内 $\left(0 \leq z^{\prime} \leq h\right)$ および帰還雷撃 路上 $\left(z^{\prime} \geq h\right)$ の電流分布が導かれている。導出された式 を以下に示す。

$$
I\left(z^{\prime}, t\right)=\left(1-\rho_{\text {top }}\right) \sum_{n=0}^{\infty}\left[\begin{array}{c}
\rho_{\text {bot }}^{n} \rho_{\text {top }}^{n} I_{m c}\left(h, t-\frac{h-z^{\prime}}{c}-\frac{2 n h}{c}\right) \\
+\rho_{\text {bot }}^{n+1} \rho_{\text {top }}^{n} I_{m c}\left(h, t-\frac{h+z^{\prime}}{c}-\frac{2 n h}{c}\right)
\end{array}\right]
$$

for $0 \leq z^{\prime} \leq h$ (高構造物)

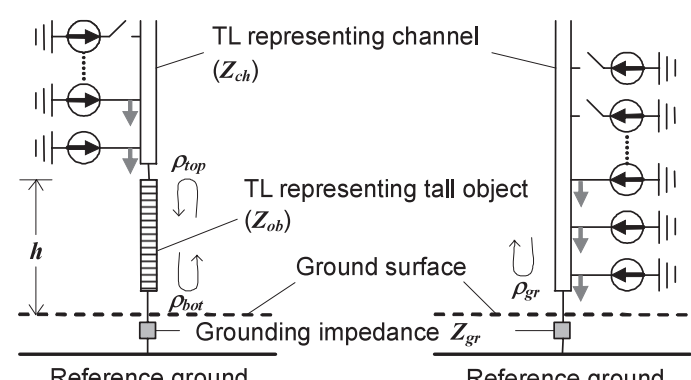

(a) Lightning strike to a tall object

(b) Lightning strike to flat ground

図 6 高構造物および平坦大地への帰還雷撃の 分布並列電流源を用いた等価モデル ${ }^{(15)}$

Fig. 6. Representation of lightning return strokes attached to a tall object and to flat ground using distributed shunt current sources. 


$$
\begin{aligned}
& I\left(z^{\prime}, t\right)=\left[\begin{array}{c}
I_{m c}\left(h, t-\frac{z^{\prime}-h}{v_{f}}\right)-\rho_{t o p} I_{m c}\left(h, t-\frac{z^{\prime}-h}{c}\right) \\
\quad+\left(1-\rho_{t o p}\right)\left(1+\rho_{t o p}\right) \\
\quad \times \sum_{n=1}^{\infty} \rho_{b o t}^{n} \rho_{t o p}^{n-1} I_{m c}\left(h, t-\frac{z^{\prime}-h}{c}-\frac{2 n h}{c}\right)
\end{array}\right] \\
& \times u\left(t-\frac{z^{\prime}-h}{v_{f}}\right) \ldots \ldots \ldots \ldots \ldots \ldots
\end{aligned}
$$

for $z^{\prime} \geq h$ (帰還雷撃路)

ここで, $\rho_{b o t}$ は高構造物下端での電流反射係数, $\rho_{t o p}$ は高構造 物を上向きに伝搬する電流波に対する高構造物上端での反射 係数, $h$ は高構造物の高さ, $I_{m c}(h, t)$ は高構造物の上端, 下端で インピーダンス整合がとられている場合 $\left(\rho_{\text {bot }}=\rho_{\text {top }}=0\right)$ に高構造物頂部および帰還雷撃路下端に流れる電流であ る。接地インピーダンスを $Z_{g r}$, 高構造物の特性インピー ダンスを $Z_{o b}$, 帰還雷撃路の等価インピーダンスを $Z_{c h}$ と すると, 電流反射係数は, $\rho_{b o t}=\left(Z_{o b}-Z_{g r}\right) /\left(Z_{o b}+Z_{g r}\right)$, $\rho_{\text {top }}=\left(Z_{o b}-Z_{c h}\right) /\left(Z_{o b}+Z_{c h}\right)$ で与えられる。

また, 図 $6(\mathrm{~b})$ の平坦大地への帰還雷撃の場合には, 電流 分布は次式で表される。

$$
I\left(z^{\prime}, t\right)=\left[I_{m c}\left(0, t-\frac{z^{\prime}}{v_{f}}\right)+\rho_{g r} I_{m c}\left(0, t-\frac{z^{\prime}}{c}\right)\right] u\left(t-\frac{z^{\prime}}{v_{f}}\right)
$$

ここで, $\rho_{g r}$ は帰還雷撃根元部 (大地) での電流反射係数, $I_{m c}(0, t)$ は帰還雷撃路の根元部でインピーダンス整合がと られている場合 $\left(\rho_{g r}=0\right)$ に流れる電流である。電流反射 係数は, $\rho_{g r}=\left(Z_{c h}-Z_{g r}\right) /\left(Z_{c h}+Z_{g r}\right)$ で与えられる。なお, 図 5 に示したモデルと同様に，分布並列電流源は下向きに のみ電流波を出力すると仮定されており，(8), (9) 式と図 6 のモデル概念図が完全に対応しているわけではない。ただ し，このモデルでは，大地面での反射は考慮している。

このモデルでは, 分布並列電流源は, 速度 $v_{f}$ で進行する 帰還雷撃波の到達によりターンオンされるが，それにより 垂直な伝送線路に流入する電流波は光速 $c$ で下向きに伝搬 すると仮定されている。雷撃路下端（高構造物頂部または 大地）で反射した電流波は光速 $c$ で上向きに伝搬し，速度 $v_{f}(<c)$ で上向きに進行する帰還雷撃波先端部に追いつい てしまう。このモデルでは，帰還雷撃先端部に追いついた 電流反射波は，その部分で消滅すると仮定されている。こ のため，このモデルを用いて計算した㷌還雷撃路上の電流 は，その下端以外において不連続な（瞬時の）立ち上がり を有する波形となる(図 8 破線参照)。なお，先端部での反 射も考慮したモデルも存在する ${ }^{(36)(37) 。 ~}$

〈3・3〉 集中直列電圧源モデルリーダチャネルを充 電された伝送線路と見なすと，地上構造物との間でアタッ チメントが生じることによって流れ始める帰還雷撃電流の ピーク值や波形は, 地上構造物の長さやインピーダンスの 影響を受けると考えられる。この充電されたリーダチャネ ルと，接地インピーダンスが $Z_{g r} \approx 0$ と近似できるような 高導電率の平坦大地との間でアタッチメントが生じた場合
に流れる帰還雷撃電流を短絡雷電流 $I_{s c}$ と定義し, それと 帰還雷撃路の等価インピーダンス $Z_{c h}$ との積 $V_{0}=Z_{c h} I_{s c}$ を 出力する電圧源をアタッチメントが生じると考えられる点 (帰還雷撃路と高構造物の接続点, 帰還雷撃路と大地の接続 点）に直列に挿入したモデルが提案されている。電圧源の 内部インピーダンスは零であるため, その存在が高構造物 内や雷撃路上の電流波の過渡現象に影響を与えることはな い。このモデルの模式図を図 7 に示す。帰還雷撃路上の電 流波の伝搬速度 $v$ と帰還雷撃波の進行速度 $v_{f}$ は等しいと仮 定されており，帰還雷撃波先端部に反射波が追いつくこと もないため, 分布並列電流源に基づくモデルが有する問題 は存在しない。高構造物内での電流波伝搬速度は光速 $c$ と 仮定されている。このモデルを対象に導出された電流分布 を次式に示す。

$$
\begin{aligned}
& I\left(z^{\prime}, t\right)=\frac{1}{Z_{c h}+Z_{o b}} V_{0}\left(h, t-\frac{h-z^{\prime}}{c}\right) \\
& +\rho_{b o t} \frac{1}{Z_{c h}+Z_{o b}} V_{0}\left(h, t-\frac{h+z^{\prime}}{c}\right) \\
& +\rho_{\text {top }} \rho_{b o t} \frac{1}{Z_{c h}+Z_{o b}} V_{0}\left(h, t-\frac{h-z^{\prime}}{c}-\frac{2 h}{c}\right) \\
& +\rho_{b o t} \rho_{t o p} \rho_{b o t} \frac{1}{Z_{c h}+Z_{o b}} V_{0}\left(h, t-\frac{h+z^{\prime}}{c}-\frac{2 h}{c}\right) \cdots \\
& =\frac{Z_{c h}}{Z_{c h}+Z_{o b}} \sum_{n=0}^{\infty}\left[\begin{array}{c}
\rho_{b o t}^{n} \rho_{\text {top }}^{n} I_{s c}\left(h, t-\frac{h-z^{\prime}}{c}-\frac{2 n h}{c}\right) \\
+\rho_{\text {bot }}^{n+1} \rho_{\text {top }}^{n} I_{s c}\left(h, t-\frac{h+z^{\prime}}{c}-\frac{2 n h}{c}\right)
\end{array}\right] \\
& =\frac{1-\rho_{\text {top }}}{2} \sum_{n=0}^{\infty}\left[\begin{array}{c}
\rho_{\text {bot }}^{n} \rho_{\text {top }}^{n} I_{s c}\left(h, t-\frac{h-z^{\prime}}{c}-\frac{2 n h}{c}\right) \\
+\rho_{\text {bot }}^{n+1} \rho_{\text {top }}^{n} I_{s c}\left(h, t-\frac{h+z^{\prime}}{c}-\frac{2 n h}{c}\right)
\end{array}\right] \\
& \ldots \ldots \ldots \ldots(10 \mathrm{a})
\end{aligned}
$$

for $0 \leq z^{\prime} \leq h$ (高構造物)

$$
\begin{aligned}
& I\left(z^{\prime}, t\right)=\frac{1}{2}\left[\begin{array}{c}
I_{s c}\left(h, t-\frac{z^{\prime}-h}{v}\right)-\rho_{t o p} I_{s c}\left(h, t-\frac{z^{\prime}-h}{v}\right) \\
+\left(1-\rho_{t o p}\right)\left(1+\rho_{t o p}\right) \\
\times \sum_{n=1}^{\infty} \rho_{b o t}^{n} \rho_{t o p}^{n-1} I_{s c}\left(h, t-\frac{z^{\prime}-h}{v}-\frac{2 n h}{c}\right)
\end{array}\right] \\
& \times u\left(t-\frac{z^{\prime}-h}{v_{f}}\right) \ldots \ldots \ldots \ldots \ldots \ldots \ldots \\
& \text { for } z^{\prime} \geq h \text { (帰還雷撃路) }
\end{aligned}
$$

また, 図 7(b) の平坦大地への帰還雷撃の場合には, 電流分 布は次式で表される。

$$
\begin{aligned}
I\left(z^{\prime}, t\right) & =\frac{1}{Z_{c h}+Z_{g r}} V_{0}\left(0, t-\frac{z^{\prime}}{v}\right)=\frac{Z_{c h}}{Z_{c h}+Z_{g r}} I_{s c}\left(0, t-\frac{z^{\prime}}{v}\right) \\
& =\frac{1+\rho_{g r}}{2} I_{s c}\left(0, t-\frac{z^{\prime}}{v}\right) \ldots \ldots \ldots \ldots \ldots \ldots(11)
\end{aligned}
$$

このモデルでは, (10) 式および(11) 式で表される電流分 布と図 7(a) および (b) の回路はほぼ完全に対応している(帰 還雷撃路を模擬する伝送線路が空気中に存在するにもかか わらず，その部分での電流波伝搬速度 $v$ が光速 $c$ より低い 


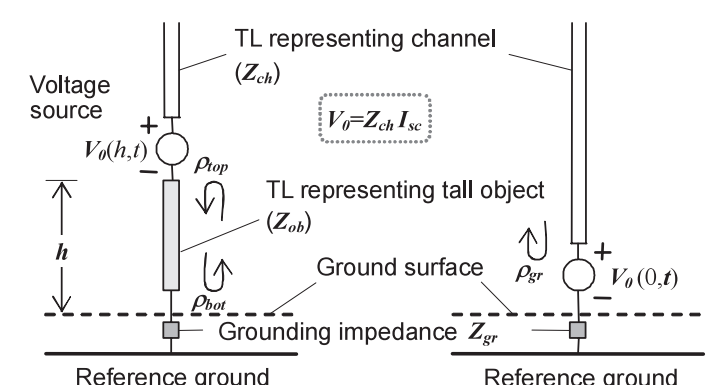

(a) Lightning strike to a tall object

(b) Lightning strike to flat ground

図 7 高構造物および平坦大地への帰還雷撃の 集中直列電圧源を用いた等価モデル(16)

Fig. 7. Representation of lightning return strokes attached to a tall object and to flat ground using a series lumped voltage source.

ことを除いて)。なお，このモデルで用いられている短絡雷 電流 $I_{s c}$ と前述した分布並列電流源モデルで用いられてい るインピーダンス整合時の雷電流 $I_{m c}$ との間には，次式で 表される関係が成立する。

$$
I_{s c}(0, t)=2 I_{m c}(0, t), \quad I_{s c}(h, t)=2 I_{m c}(h, t) \cdots \cdots
$$

高構造物内の電流分布については, 集中直列電圧源モデ ルと分布並列電流源モデルは完全に一致している [(10a) 式 と (8a) 式参照]。帰還雷撃路上の電流分布については，両 者は異なるが，分布並列電流源モデルにおいて，帰還雷撃 路を模擬する伝送線路上を伝搬する電流波の伝搬速度を $c$ ではなく $v$ と設定すると $[(8 \mathrm{~b})$ 式の第 2 項目および第 3 項 目の $\left(z^{\prime}-h\right) / c$ が $\left(z^{\prime}-h\right) / v$ となる], 両モデルによる帰還 雷撃路上の電流分布は完全に一致する $[(10 b)$ 式と $(8 b)$ 式 参照]。

図 8 に，(10b) 式と (8b) 式を用いて計算した帰還雷撃路 上の電流分布を示す。なお，この計算において， $h=100 \mathrm{~m}$, 電流 $\rho_{b o t}=1\left(Z_{g r}=0\right), \rho_{t o p}=-0.5$ (例えば, $Z_{c h}=600 \Omega$, $Z_{o b}=200 \Omega$ に相当)， $v=0.5 c$ と設定した。帰還雷撃路上 での（反射）電流波の伝搬速度の相違 $(v$ 対 $c)$ により, 帰還 雷撃路の下端以外において両計算波形に相違が生じている。

なお，(10a）式で表される電流を $z^{\prime}=0$ （高構造物下端， 大地面）において， $t=0$ から 0 まで積分した值は，(11) 式で表される電流を $z^{\prime}=0$ (帰還雷撃路根元部, 大地面) において， $t=0$ から 0 まで積分した值に等しいことが示 されている(20)。このことは，このモデルにおいては，高構 造物の有無に関わらず，大地に運ばれる総電荷量は同じで あることを示している。また，(10b) 式に $h=0$ を代入し， 式変形を行うと (11) 式が得られることも示されている ${ }^{(16)}$ 以上のことから，図 7 のモデル回路あるいは (10a), (10b) および (11) 式は, 高構造物雷撃と平坦大地雷撃の比較をす る際に有用かつ矛盾の少ないモデルであるといえる。この モデルでは，構造物頂部あるいは大地から発せられる上向 きリーダは考慮されていないが，その存在を考慮したモデ ル(19)(38) も提案されている。

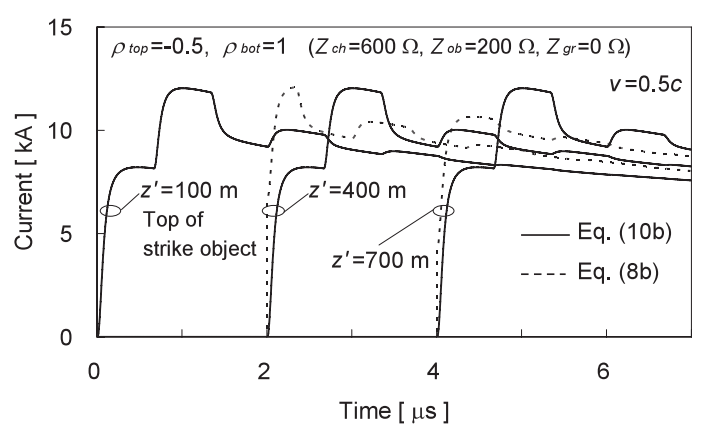

図 8 (8b) 式および (10b) 式を用いて計算した 高さ $100 \mathrm{~m}$ の構造物に帰還雷撃が生じた 場合の帰還雷撃路上の電流分布

Fig. 8. Current waveforms at different heights along a vertical lightning channel attached to a $100 \mathrm{~m}$ high object calculated using (8b) and (10b).

また, $\rho_{g r}=1\left(Z_{g r}=0\right), \rho_{t o p}=-0.5\left(Z_{c h}=600 \Omega\right.$, $\left.Z_{o b}=200 \Omega\right)$ の場合，(10) 式および (11) 式より，高構 造物雷撃時には $\left(1-\rho_{t o p}\right) I_{s c} / 2=0.75 I_{s c}$ の電流が初期に 高構造物と帰還雷撃路に流入するが，平坦大地雷撃時には $\left(1+\rho_{g r}\right) I_{s c} / 2=I_{s c}$ の電流が州還雷撃路に流入することにな り，初期の流入電流ピーク值は両ケースで異なる。このこ とは，分布並列電流源モデルにおいても同様である。これ らは, 帰還雷撃電流值は地上構造物の存在やそのインピー ダンス值に依存するという考えに立脚している。一方，初 期の帰還雷撃電流值は, 地上構造物の存在やインピーダン スに依存しないと考える研究者もおり，その観点から内部 インピーダンスが零の（少し奇妙な）集中直列電流源を含 むモデル(39) も提案されている。

\section{4. 雷電磁界パルスの計算式}

〈4・1〉 ローレンツ条件に基づく導出式＼cjkstart本節では，工 学モデルによって与えられる電流の時間空間分布 $\boldsymbol{I}\left(z^{\prime}, t\right)$ を 基に，そこから放射される磁界および電界を計算するため の式（電流と磁界, 電界の関係式）として, ほぼ独占的に 利用されている式(12)を示す。

磁束密度 $\boldsymbol{B}$ （または磁界 $\boldsymbol{H}$ ）については，帰還雷撃の工 学モデルによって与えられる電流分布 $\boldsymbol{I}\left(z^{\prime}, t\right)$ からべクトル ポテンシャル $\boldsymbol{A}$ を求め, それを $\boldsymbol{B}=\operatorname{rot} \boldsymbol{A}$ の関係に代入し て，磁束密度 $\boldsymbol{B}$ （と電流 $\boldsymbol{I}$ の関係）を導出している。

電界 $\boldsymbol{E}$ については，帰還雷撃の工学モデルによって与え られる電流分布 $\boldsymbol{I}\left(z^{\prime}, t\right)$ からベクトルポテンシャル $\boldsymbol{A}$ を求 め，またローレンツ条件 $\operatorname{div} \boldsymbol{A}+1 / c^{2} \cdot \partial \phi / \partial t=0$ を用いて スカラーポテンシャル $\phi$ を $\boldsymbol{A}$ あるい $\boldsymbol{I}$ で表し, これらを電 界の一般式 $\boldsymbol{E}=-\operatorname{grad} \phi-\partial \boldsymbol{A} / \partial t$ に代入して, 電界 $\boldsymbol{E}$ （と 電流 $\boldsymbol{I}$ の関係）を導出している。

この手法で導出された完全導体大地面上における垂直な 帰還雷撃路から水平距離 $d$ 離れた点の $\varphi$ 方向 (水平方向) 磁 束密度 $B_{\varphi}$ および垂直方向電界 $E_{z}$ の計算式を以下に示す。 


$$
\begin{aligned}
& B_{\varphi}(d, t)= \frac{1}{2 \pi \varepsilon_{0} c^{2}} \int_{0}^{L^{\prime}(t)}\left[\begin{array}{c}
\frac{\sin \alpha\left(z^{\prime}\right)}{R^{2}\left(z^{\prime}\right)} I\left(z^{\prime}, t-R\left(z^{\prime}\right) / c\right) \\
+\frac{\sin \alpha\left(z^{\prime}\right)}{c R\left(z^{\prime}\right)} \frac{\partial I\left(z^{\prime}, t-R\left(z^{\prime}\right) / c\right)}{\partial t}
\end{array}\right] d z^{\prime} \\
&+\frac{1}{2 \pi \varepsilon_{0} c^{2}} \frac{\sin \alpha\left(L^{\prime}\right)}{c R\left(L^{\prime}\right)} I\left(L^{\prime}, t-R\left(z^{\prime}\right) / c\right) \frac{d L^{\prime}}{d t} \\
& \ldots \ldots \ldots \ldots \ldots \ldots(13) \\
& E_{z}(d, t)= \frac{1}{2 \pi \varepsilon_{0}} \int_{0}^{L^{\prime}(t)} \frac{2-3 \sin ^{2} \alpha\left(z^{\prime}\right)}{R^{3}\left(z^{\prime}\right)} \int_{t_{b}}^{t} I\left(z^{\prime}, \tau-R\left(z^{\prime}\right) / c\right) d \tau d z^{\prime} \\
&+\frac{1}{2 \pi \varepsilon_{0}} \int_{0}^{L^{\prime}(t)} \frac{2-3 \sin ^{2} \alpha\left(z^{\prime}\right)}{c R^{2}\left(z^{\prime}\right)} I\left(z^{\prime}, t-R\left(z^{\prime}\right) / c\right) d z^{\prime} \\
&-\frac{1}{2 \pi \varepsilon_{0}} \int_{0}^{L^{\prime}(t)} \frac{\sin ^{2} \alpha\left(z^{\prime}\right)}{c^{2} R\left(z^{\prime}\right)} \frac{\partial I\left(z^{\prime}, t-R\left(z^{\prime}\right) / c\right)}{\partial t} d z^{\prime} \\
&-\frac{1}{2 \pi \varepsilon_{0}} \frac{\sin ^{2} \alpha\left(L^{\prime}\right)}{c^{2} R\left(L^{\prime}\right)} I\left(z^{\prime}, t-R\left(z^{\prime}\right) / c\right) \frac{\partial L^{\prime}}{\partial t} \cdots \ldots(14)
\end{aligned}
$$

上式の $L^{\prime}(t)$ は帰還雷撃路から水平距離 $d$ 離れた大地面上の 観測者から見た帰還雷撃波頭部の高さ, $R\left(z^{\prime}\right)=\left(z^{\prime 2}+d^{2}\right)^{1 / 2}$, $\sin \alpha=z^{\prime} / R, t_{b}=z^{\prime} / v_{f}\left(v_{f}\right.$ : 帰還雷撃波の伝搬速度）で ある。また， $1 / R^{3} ， 1 / R^{2}, 1 / R$ に比例する各項は，それぞ れ静電界成分, 誘導成分, 放射成分と呼ばれている。なお, (13), (14) 式の最後の項は, 帰還雷撃波頭部における電流 が不連続でない場合には，0となる。

〈4·2〉 電荷連続条件に基づく導出式＼cjkstart本節では，電 荷連続条件を用いて最近導出された電界計算式（電流と電 界の関係式) (17)を示す。

この手法では，まず帰還雷撃の工学モデルによって与え られる電流分布 $\boldsymbol{I}\left(z^{\prime}, t\right)$ と電荷連続条件から帰還雷撃路上の (線) 電荷密度 $\rho^{*}$ を求め, それを用いてスカラーポテンシャ ル $\phi$ を求めている。また $I\left(z^{\prime}, t\right)$ からべクトルポテンシャル $\boldsymbol{A}$ を求め, それらを電界の一般式 $\boldsymbol{E}=-\operatorname{grad} \phi-\partial \boldsymbol{A} / \partial t$ に 代入して，電界 $\boldsymbol{E}$ を導出している。

この手法で導出された完全導体大地面上における垂直な 帰還雷撃路から水平距離 $d$ 離れた点の垂直方向電界 $E_{z}$ の 計算式を以下に示す。

$$
\begin{aligned}
& E_{z}(d, t)=-\frac{1}{2 \pi \varepsilon_{0}} \int_{0}^{L^{\prime}(t)} \frac{z^{\prime}}{R^{3}\left(z^{\prime}\right)} \rho *\left(z^{\prime}, t-R\left(z^{\prime}\right) / c\right) d z^{\prime} \\
&-\frac{1}{2 \pi \varepsilon_{0}} \int_{0}^{L^{\prime}(t)} \frac{z^{\prime}}{c R^{2}\left(z^{\prime}\right)} \frac{\partial \rho^{*}\left(z^{\prime}, t-R\left(z^{\prime}\right) / c\right)}{\partial t} d z^{\prime} \\
&-\frac{1}{2 \pi \varepsilon_{0}} \int_{0}^{L^{\prime}(t)} \frac{1}{c^{2} R\left(z^{\prime}\right)} \frac{\partial I\left(z^{\prime}, t-R\left(z^{\prime}\right) / c\right)}{\partial t} d z^{\prime} \\
&-\frac{1}{2 \pi \varepsilon_{0}} \frac{L^{\prime}(t)}{c R^{2}\left(L^{\prime}\right)} \rho^{*}\left(L^{\prime}, t-R\left(L^{\prime}\right) / c\right) \frac{d L^{\prime}(t)}{d t} \\
&-\frac{1}{2 \pi \varepsilon_{0}} \frac{1}{c^{2} R\left(L^{\prime}\right)} I\left(L^{\prime}, t-R\left(z^{\prime}\right) / c\right) \frac{d L^{\prime}(t)}{d t} \\
& \text { ただ }, \frac{\partial \rho^{*}\left(z^{\prime}, t-R\left(z^{\prime}\right) / c\right)}{\partial t}=-\left.\frac{\partial I\left(z^{\prime}, t-R\left(z^{\prime}\right) / c\right)}{\partial z^{\prime}}\right|_{t-\frac{R\left(z^{\prime}\right)}{c}=\text { const. }}
\end{aligned}
$$

(14) 式の各項との対応から, (15) 式の $1 / R^{3}, 1 / R^{2}, 1 / R$ に 比例する各項は，それぞれ静電界成分，誘導成分，放射成 分と見なすことができる。なお，(15) 式の最後の 2 項は， 帰還雷撃波頭部における電荷, および電流が不連続でない
場合には，0 となる。

(15) 式により計算した任意の $d$ における電界波形（各項 の和）は，(14) 式を用いて計算した電界波形と完全に一致す るが，各項の寄与分はそれぞれ異なることが示されている。

$\langle\mathbf{4} \cdot \mathbf{3}\rangle$ 帰還雷撃波の伝搬速度が光速に等しい場合の導 出式本節では, 雷電流波が, 減衰および变わいするこ となく, 垂直な雷撃路を上向きに伝搬する場合における完 全導体大地面上における $\varphi$ 方向磁束密度 $B_{\varphi}$ および垂直方 向電界 $E_{z}$ の計算式 ${ }^{(18)}$ を示す。次式が導出された式である。

$$
\begin{aligned}
& B_{\varphi}(d, t)=\frac{I(0, t-d / c)}{2 \pi \varepsilon_{0} c^{2} d} . \\
& E_{z}(d, t)=\frac{I(0, t-d / c)}{2 \pi \varepsilon_{0} c d} .
\end{aligned}
$$

(16)，(17) 式より，上述の条件が成立する場合には， $B_{\varphi}$ および $E_{z}$ 波形は, 帰還雷撃路根元部の電流波形 $I(0, t)$ と相 似になり, 振幅は根元部からの水平距離 $d$ に反比例するこ とがわかる。これらは双対円錐アンテナ周囲に作られる磁 束密度および電界の式 ${ }^{(35)}$ に等しい（球面状 TEM モード）。 また，(16)，(17) 式を用いて計算した $B_{\varphi}$ および $E_{z}$ 波形は, $v_{f}=v=c$ と設定して, (13), (14) 式を用いて計算した $B_{\varphi}$ および $E_{z}$ 波形と完全に一致することが示されている(18)。

\section{5. 雷電磁界パルスに与える高構造物の影響}

$\langle\mathbf{5} \cdot \mathbf{1}\rangle$ 近傍電界の低減と遠方電界 - 磁界の増大 高 構造物への帰還雷撃に起因した完全導体大地面上の垂直電 界 $E_{z \_ \text {tall }}$ とそれに対応する平坦大地への帰還雷撃に起因し た垂直電界 $E_{z_{-} \text {flat }}$ との比, および同様の帰還雷撃に起因し た水平 $(\varphi$ 方向 $)$ 磁界 $H_{\varphi \_ \text {tall }}$ と $H_{\varphi_{-} \text {flat }}$ の比の計算結果を 図 9 に示す。同図の縦軸は $E_{z_{z} \text { tall }}$ と $E_{z_{-} \text {flat }}$ の比, または $H_{\varphi_{\text {_tall }}}$ と $H_{\varphi_{-} \text {flat }}$ の比である。この比が 1 より小さければ, 高構造物への雷撃時の方が電界または磁界が小さくなるこ とを示しており，この比が 1 より大きければ，高構造物雷 撃時の方が電界または磁界が大きくなることを示している。 図 9 の横軸は, 帰還雷撃路からの水平距離であり $30 \mathrm{~m}$ か

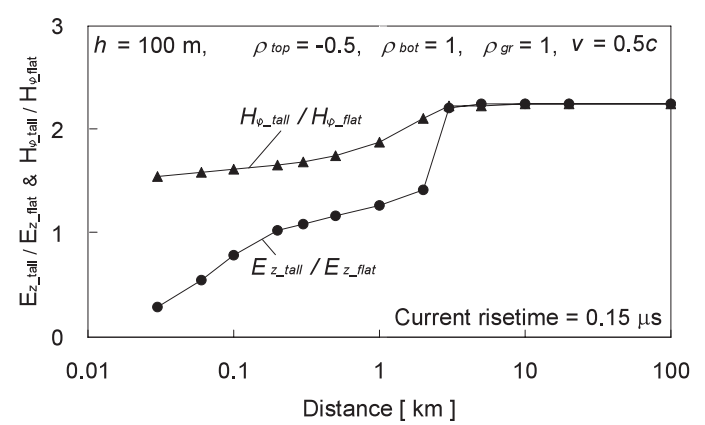

困 9 高さ $100 \mathrm{~m}$ の構造物への雷撃に起因した垂 直電界 $E_{z_{z} \text { tall }}$ と平坦大地雷撃に起因した垂直電界 $E_{z_{-} \text {flat }}$ の比の帰還雷撃路からの距離依存性, およ び水平磁界 $H_{\varphi \_ \text {tall }}$ と $H_{\varphi_{-} \text {flat }}$ の比の距離依存性 ${ }^{(19)}$ Fig. 9. Ratios $E_{z_{-} \text {tall }} / E_{z_{-} \text {flat }}$ and $H_{\varphi_{-} \text {tall }} / H_{\varphi_{-} \text {flat }}$ as a function of horizontal distance $d$ from the lightning channel. 


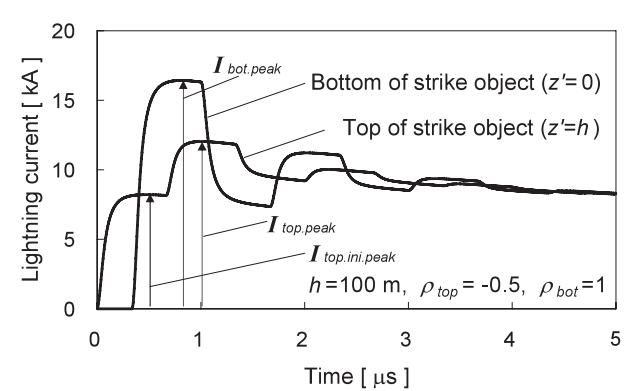

(a) Currents at the top and bottom of a $100 \mathrm{~m}$ high strike object

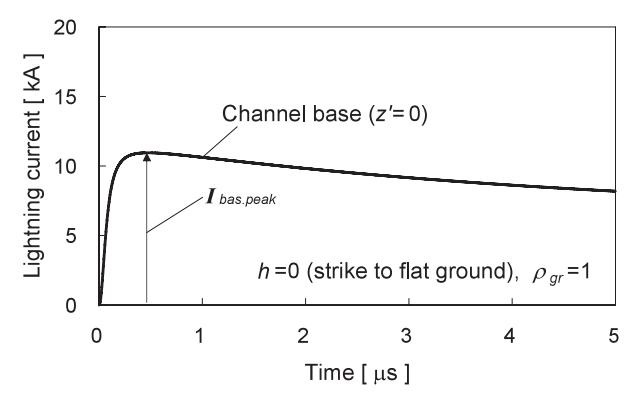

(b) Current at the channel base for the case of strike to flat ground

図 10 (10a) 式を用いて計算した高さ $100 \mathrm{~m}$ の 構造物への雷撃時の構造物上端・下端の電流 計算波形, および (11) 式を用いて計算した平坦 大地雷撃時の雷撃路下端の電流計算波形

Fig. 10. Waveforms of current for a lightning strike to a $100 \mathrm{~m}$ high object at the top and bottom of the object calculated using (10a), and waveform of current at the channel base for the same lightning strike to flat ground calculated using (11).

ら $100 \mathrm{~km}$ の範囲における結果を示している。

なお，この計算では，高構造物雷撃時の電流分布として (10a), (10b) 式を, 平坦大地雷撃時の電流分布として (11) 式を用いた。困 10(a)に高構造物雷撃時の高構造物の上端 および下端における電流計算波形を, 同図 (b)に平坦大地雷 撃時の雷撃路下端における電流計算波形を示す。また，電 界および磁界の計算には，(14)および (13) 式を用いた。帰 還雷撃路から水平距離 $d=50 \mathrm{~km}$ 離れた大地面上における $\varphi$ 方向磁界, $H_{\varphi \_ \text {tall }}$ および $H_{\varphi_{-} \text {flat }}$ の計算波形を図 11 に示 す。構造物の高さは $h=100 \mathrm{~m}$, 構造物下端の電流反射係数 は $\rho_{b o t}=1\left(Z_{g r}=0\right)$, 上端の反射係数は $\rho_{t o p}=-0.5$ (例え ば, $Z_{c h}=600 \Omega, Z_{o b}=200 \Omega$ に相当), 帰還雷撃路上の電 流伝搬速度は $v=0.5 c$ と設定した。また，短絡雷電流波形 $I_{s c}(0, t)$ および $I_{s c}(h, t)$ としては, 後続帰還雷撃の典型的な 電流波形を模擬していると考えられている波形(1)を用いた。 この電流波形の立ち上がり時間（10-90\%）は $0.15 \mu \mathrm{s}$ であ り，ピーク值は $I_{\text {sc.peak }}=11 \mathrm{kA}$ である。図 10(a)より，高 構造物上端に初期に流入する電流のピーク值は $I_{\text {top.ini.peak }}=$ $\left(1-\rho_{\text {top }}\right) I_{\text {sc.peak }} / 2=8.2 \mathrm{kA}$, 大地面からの反射波が戻っ てきた後のピーク值は $I_{\text {top.peak }}=\left[1+\left(1+\rho_{\text {top }}\right) \rho_{\text {bot }}\right](1-$ $\left.\rho_{\text {top }}\right) I_{\text {sc.peak }} / 2 \approx 12 \mathrm{kA}$ である。高構造物下端の電流ピーク 值は $I_{\text {top.peak }}=\left(1+\rho_{\text {bot }}\right)\left(1-\rho_{\text {top }}\right) I_{\text {sc.peak }} / 2=16 \mathrm{kA}$ であり, 上端でのピーク值に比べてかなり大きい。一方, 図 10(b)

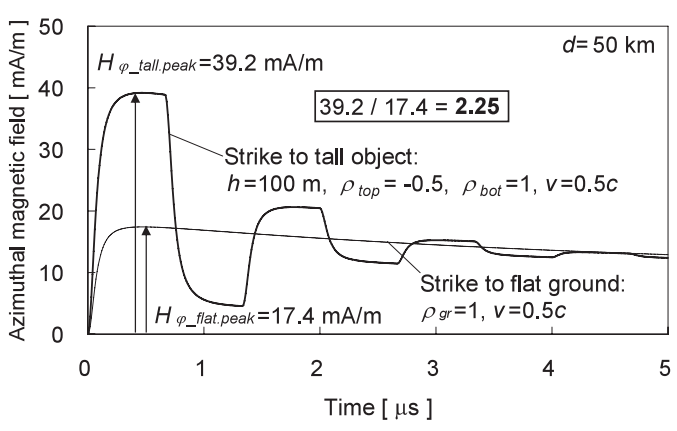

図 $11 d=50 \mathrm{~km}$ における高さ $100 \mathrm{~m}$ の構造物へ の雷撃に起因した $H_{\varphi \_ \text {tall.peak }}$ の計算波形，および 平坦大地代劇に起因した $\varphi$ 方向磁界 $H_{\varphi_{-} \text {flat.peak }}$

Fig. 11. Azimuthal magnetic field waveforms, $H_{\varphi_{-} \text {tall.peak }}$ and $H_{\varphi_{-} \text {flat.peak }}$, calculated on perfectly conducting ground at distance $d=50 \mathrm{~km}$ for a lightning strike to a $100 \mathrm{~m}$ high object and for the same strike to flat ground.

より, 平坦大地雷撃時の雷撃路下端における電流ピーク值 は $I_{\text {bas.peak }}=\left(1+\rho_{\text {gr }}\right) I_{\text {sc.peak }} / 2=11 \mathrm{kA}$ である。

図 9 より, 高さ $100 \mathrm{~m}$ の雷撃構造物から $200 \mathrm{~m}$ の範囲内 の垂直電界は, 高構造物の存在により低減されること, この 距離を越える領域では逆に増大し, $3 \mathrm{~km}$ 付近で 2.25 倍に達 し飽和することがわかる。 $\varphi$ 方向磁界については, 高構造物 の存在により, 全ての距離において, 増大している。また, 垂直電界と同様に， $\varphi$ 方向磁界も $3 \mathrm{~km}$ 付近で 2.25 倍に達 し飽和している。ただし, 図 9 は, 構造物での雷電流伝搬 時間 $0.33 \mu \mathrm{s}=h / c$ よりも短い立ち上がり時間 $(0.15 \mu \mathrm{s})$ を 有する電流波形 $I_{s c}$ を用いた場合の計算例であるが, $0.33 \mu \mathrm{s}$ よりも長い立ち上がり時間を有する $I_{s c}$ を用いた場合には, 遠方電界および磁界の増大は抑制される。例えば, 立ち上 がり時間 $1.4 \mu \mathrm{s}$ の $I_{s c}$ を用いた場合には, $100 \mathrm{~m}$ の雷撃構造 物の存在による遠方電界, 磁界の増大は 1.13 倍にすぎない。

なお，高構造物近傍における垂直電界の低減効果につい ては，〈3·2〉節で述べた高構造物雷撃モデルを用いて，さ らに検討が行われており, 高構造物下端の電流反射係数が $\rho_{b o t}=0.8$ 程度より小さい場合 $\left(Z_{g r}>20 \Omega\right)$ 高構造物の高 さの $1 / 10$ 程度の水平距離の範囲内に招ける大地面上の垂直 電界の極性が反転する ${ }^{(22)}$ に至ることが示されている。

$\langle\mathbf{5 \cdot 2}\rangle$ 遠方磁界, 電界の増大係数 平坦大地への帰還 雷撃に起因した遠方（水平距離 $d$ ）での $\varphi$ 方向磁界のピー ク值 $H_{\varphi_{-} \text {flat.peak }}$ は, 放射成分のみを考慮して, 次式で与え られる。

$$
\begin{array}{r}
H_{\varphi_{-} \text {flat.peak }}(d)=\frac{1}{2 \pi c d} v I_{\text {bas.peak }}=\frac{1}{2 \pi c d} v \frac{1+\rho_{g r}}{2} I_{\text {sc.peak }} \\
\ldots \ldots \ldots \ldots \ldots \ldots
\end{array}
$$

なお, $I_{\text {bas.peak }}$ は平坦大地雷撃時における雷撃路根元部 $\left(z^{\prime}=0\right)$ における電流のピーク值である [図 10(b) にお いて $11 \mathrm{kA}] 。(11)$ 式より， I bas.peak は短絡雷電流のピーク 值 $I_{\text {sc.peak }}$ を用いて, $\left(1+\rho_{g r}\right) I_{\text {sc.peak }} / 2$ で表される。

一方, 高構造物雷撃に起因した遠方での $\varphi$ 方向磁界のピー ク值 $H_{\varphi \_ \text {tall.peak }}$ は, 速度 $v$ で高構造物上端から上向きに雷 
撃路を伝搬する電流波による寄与と，速度 $c$ で下向きに高 構造物を伝搬する電流波の寄与の和として, 次式で与えら れる。

$$
\begin{aligned}
H_{\varphi_{-} \text {tall.peak }}(d) & =\frac{1}{2 \pi c d} v I_{\text {top.ini.peak }}+\frac{1}{2 \pi c d} c I_{\text {top.ini.peak }} \\
& =\frac{1}{2 \pi c d}(v+c) \frac{1-\rho_{\text {top }}}{2} I_{\text {sc.peak }}
\end{aligned}
$$

(19) 式中の $I_{\text {top.ini.peak }}$ は高構造物雷撃時における雷撃路根元 部または高構造物頂部 $\left(z^{\prime}=h\right)$ における初期の（大地からの 反射波が戻ってくる前の) 電流のピーク值である [図 10(a) において $8.2 \mathrm{kA}]$ 。(10) 式より，I Iop.ini.peak は短絡雷電流の ピーク值 $I_{\text {sc.peak }}$ を用いて， $\left(1-\rho_{\text {gr }}\right) I_{\text {sc.peak }} / 2$ で表される。 なお， $H_{\varphi \_t a l l . p e a k}$ に寄与するのは $I_{\text {top.ini.peak }}$ [図 10(a)にお いて $8.2 \mathrm{kA}$ ] であり，大地からの反射波到来以降のピーク 值 $I_{\text {top..peak }}$ ［図 10(a) において $12 \mathrm{kA}$ ］ではない。

(19) 式で与えられる $H_{\varphi_{-} \text {tall.peak }}$ (18) 式で与えられる $H_{\varphi_{-} \text {flat.peak }}$ の比をとると, 高構造物雷撃時の遠方界増大係 数 $k_{\text {tall }}{ }^{(20)}$ が次式のように得られる。

$$
k_{\text {tall }}=H_{\varphi_{-} \text {tall.peak }}(d) / H_{\varphi_{-} \text {flat.peak }}(d)=\frac{(v+c)\left(1-\rho_{\text {top }}\right)}{v\left(1+\rho_{g r}\right)}
$$

(20) 式に, $v=0.5 c, \rho_{\text {top }}=-0.5$ (例えば, $Z_{c h}=600 \Omega$, $Z_{o b}=200 \Omega$ に相当 $), \rho_{g r}=1\left(Z_{g r}=0\right)$ を代入すると, $k_{\text {tall }}=2.25$ が得られ, 図 9 の $3 \mathrm{~km}$ 以遠での磁界の比および 電界の比に一致する。なお，(20) 式の右辺は電界の放射成 分のみを考慮した計算からも同様に導くことが可能である。

$\langle\mathbf{5} \cdot \mathbf{3}\rangle$ 遠方磁界一雷電流変換式 落雷位置標定システ 厶の雷電流推定式（測定磁界一雷電流変換式）の試験や校正 を，平坦大地からのロケット誘雷での雷電流測定值と遠方 磁界測定值により行う場合には，雷撃路下端付近の電流波 形 $I(0, t)$ は図 10(b) に近いものと考えられ，また $I(0, t)$ の ピーク值と遠方磁界のピーク值の関係は (18) 式の上段で良 好に近似されると考えられる。このことから，この場合に は遠方磁界ピーク值一雷撃路根元部電流ピーク值 $I_{\text {bas.peak }}$ の 変換係数 $F_{\text {flat }}$ は次式で与えられる。

$$
F_{\text {flat }}=\frac{I_{\text {bas. peak }}}{H_{\varphi_{-} \text {flat. peak }}}=\frac{2 \pi c d}{v} \ldots \ldots \ldots \ldots \ldots \ldots
$$

一方, 高構造物雷撃時の雷電流測定值と遠方磁界測定值 により落雷位置標定システムの雷電流推定式の試験や校正 を行う場合には，図 9 および(20) 式で示したように遠方磁 界が増大すること，図 10(a) で明らかなように高構造物で の雷電流のピーク值は測定位置 (上端または下端付近) およ び時間 (上端電流の場合, 初期ピークまたは大地面からの反 射波到来以降の第 2 ピーク）に依存することを考慮する必 要がある [図 10(a)において, 高構造物上端電流の初期ピー ク值は $I_{\text {top.ini.peak }}=8.2 \mathrm{kA}$, 第 2 ピークは $I_{\text {top.peak }}=12 \mathrm{kA}$, 下端電流のピーク值は $\left.I_{\text {bot.peak }}=16 \mathrm{kA}\right]$ 。
遠方磁界ピーク值一高構造物上端雷電流初期ピーク值の 変換係数 $F_{\text {tall.ini.top }}$ は, (19) 式より, 次式で与えられる。

$$
F_{\text {tall.ini.top }}=\frac{I_{\text {top.ini.peak }}}{H_{\varphi_{\text {_tall.peak }}}}=\frac{2 \pi c d}{v+c}=\frac{v}{v+c} F_{\text {flat }}
$$

また, 遠方磁界ピーク值一高構造物上端雷電流第 2 ピー ク值 $I_{\text {top.peak }}$ の変換係数 $F_{\text {tall.top }}$ は, $I_{\text {top.peak }}=[1+(1+$ $\left.\left.\rho_{\text {top }}\right) \rho_{\text {bot }}\right] I_{\text {top.peak }}$ および (22) 式より, 次式で与えられる。

$$
\begin{aligned}
F_{\text {tall.top }} & =\frac{I_{\text {top.peak }}}{H_{\varphi \_ \text {tall.peak }}}=\frac{\left[1+\left(1+\rho_{\text {top }}\right) \rho_{\text {bot }}\right] I_{\text {top.ini.peak }}}{H_{\varphi \_t \text { tall.peak }}} \\
& =\left[1+\left(1+\rho_{\text {top }}\right) \rho_{\text {bot }}\right] \frac{v}{v+c} F_{\text {flat }} \cdots \cdots(23)
\end{aligned}
$$

さらに, 遠方磁界ピーク值一高構造物下端雷電ピーク值 $I_{\text {bot.peak }}$ の変換係数 $F_{\text {bot.top }}$ は, $I_{\text {bot.peak }}=\left(1+\rho_{\text {bot }}\right) I_{\text {top.peak }}$ および(22) 式より，次式で与えられる。

$$
\begin{aligned}
F_{\text {tall.bot }} & =\frac{I_{\text {bot.peak }}}{H_{\varphi_{\text {_tall.peak }}}}=\frac{\left(1+\rho_{\text {bot }}\right) I_{\text {top.tini.peak }}}{H_{\varphi_{\text {ttall.peak }}}} \\
& =\left(1+\rho_{\text {bot }}\right) \frac{v}{v+c} F_{\text {flat }} \ldots \ldots \ldots \ldots \ldots
\end{aligned}
$$

例えば, $v=0.5 c, \rho_{b o t}=1, \rho_{t o p}=-0.5$ の場合, 各変換 係数は, $F_{\text {tall.ini.top }}=0.33, F_{\text {tall.top }}=0.5, F_{\text {tall.bot }}=0.67$ と なる。文献 (33) では, 高さ $553 \mathrm{~m}$ の CN タワー上端付近で 実測された雷電流ピーク值 [図 10(a)の第 2 ピークに相当] は落雷位置標定システムの推定電流值の 0.38 倍程度である ことを実験的に示している。(23) 式の与える $F_{\text {tall.top }}=0.5$ は, 実測されたこの比 0.38 と比較的良好に一致している。

\section{6. 結言}

本資料では，帰還雷撃の工学モデルと同モデルを用いた 雷電磁界パルス計算についての最近の研究動向と研究成果 を整理し，紹介した。第 2 章では，平坦大地への帰還雷撃 の工学モデルとして頻繁に用いられている TLおよび TCS モデルについて説明した。さらに，実測された雷電磁界パ ルス波形の特徴の全てを再現できる最新のモデルについて

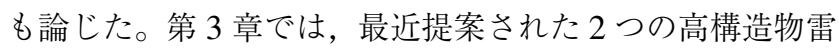
撃モデル (分布並列電流源モデルと集中直列電圧源モデル) の相違と等価性について論じた。第 4 章では, 工学モデル によって与えられる雷電流の時間空間分布を基に，そこか ら放射される磁界および電界を計算するための式を示した。 電界計算式としては，ローレンツ条件を用いて導出され古 くから用いられている式と電荷連続条件を用いて最近導出 された式を示した。また，帰還雷撃波の伝搬速度が光速で， 電流波が減衰および变わいしない場合の磁界, 電界計算式 についても述べた。第 5 章では，高構造物を含む帰還雷撃 の工学モデルを用いた計算により明らかにされた幾つかの 新事実, 例えば, 高構造物の存在により近傍電界は低減さ れる一方で遠方電界および磁界は増大すること, などにつ いて述べた。

本資料を作成するにあたり，ご支援およびご助言を賜っ 
た同志社大学の雨谷昭弘教授，長岡直人教授，東京大学の 石井勝教授，フロリダ大学の V.A. Rakov 教授に感謝致しま す。また，本資料に関わる研究の一部は科学技術研究費補 助金若手研究 B（18760220）および日揮・実吉奨学会の補 助を受けて行われたことを記し，関係各位に感謝致します。 (平成 19 年 11 月 15 日受付)

\section{文献}

(1) C.A. Nucci, G. Diendoefer, M.A. Uman, F. Rachidi, M. Ianoz, and C. Mazzetti: "Lightning return stroke current model with specified channelbase current: A review and comparison", J. Geophys. Res., Vol.95, pp.20395-20408 (1990)

(2) V.A. Rakov and M.A. Uman: "Review and evaluation of lightning return stroke models including some aspects of their application", IEEE Trans. Electromagn. Compat., Vol.40, No.4, pp.403-426 (1998)

(3) 例えば, R.D. Hill: “Channel heating in return stroke lightning”, J. Geophys. Res., Vol.76, pp.637-645 (1971)

（4）例えば, S. Kato, T. Narita, T. Yamada, and E. Zaima: "Simulation of electromagnetic field in lightning to tall tower", Proc. 11th Int. Symp. High Voltage Engineering, No.467, London, UK (1999)

（5）例えば，S. Visacro and A. De Conti: "A distributed-circuit return-stroke model allowing time and height parameter variation to match lightning electromagnetic field waveform signatures", Geophys. Res. Lett., Vol.32, L23805, doi:10.1029/2005GL024336 (2005)

(6) Y. Baba and V.A. Rakov: "Electromagnetic models of the lightning return stroke", J. Geophys. Res., Vol.112, D04102, doi:10.1029/2006JD007222 (2007)

(7) Y. Baba and V.A. Rakov: "Applications of electromagnetic models of the lightning return stroke”, IEEE Trans. Power Delivery, Vol.23, No.2 (2008)

( 8 ) S. Yokoyama: "Calculation of lightning-induced voltages on overhead multiconductor systems", IEEE Trans. Power Apparatus Syst., Vol.103, No.1, pp.100-108 (1984)

(9) M. Ishii, K. Michishita, Y. Hongo, and S. Oguma: "Lightning-induced voltage on an overhead wire dependent on ground conductivity", IEEE Trans. Power Delivery, Vol.9, No.1, pp.109-118 (1994)

(10) K. Michishita and M. Ishii: "Analysis of observed lightning-induced voltages by taking account of horizontal E-field", T. IEE Japan, Vol.120-B, No.10, pp.1304-1308 (2000-10) (in Japanese) 道下幸志・石井 勝 :「実雷撃に伴って観測された誘導電圧の水平 電界を考慮した解析」, 電学論 B, 120, 10, pp.1304-1308 (2000-10)

(11) F. Rachidi: "Formulation of the field-to-transmission line coupling equations in terms of magnetic excitation field", IEEE Trans. Electromagn. Compat., Vol.35, No.3, pp.404-407 (1993)

(12) M.A. Uman, D.K. McLain, and E.P. Krider: "The electromagnetic radiation from a finite antenna", Amer. J. Phys., Vol.43, pp.33-38 (1975)

(13) F. Heidler: "Traveling current source model for LEMP calculation", Proc. $6^{\text {th }}$ Int. EMC Zurich Symp., No.29F2 (1985)

(14) S. Miyazaki, M. Ishii, and Y. Baba: "Reproduction of features of electromagnetic field waveforms associated with lightning return stroke", IEEJ Trans. PE, Vol.125, No.5, pp.544-550 (2005-5) (in Japanese) 宮䇂 悟·石井 勝 - 馬場吉弘：「帰還雷撃に伴う電磁界波形の特 徵の再現」, 電学論 B, 125, 5, pp.544-550 (2005-5)

(15) F. Rachidi, V.A. Rakov, C.A. Nucci, and J.L. Bermudez: "Effect of vertically extended strike object on the distribution of current along the lightning channel", J. Geophys. Res., Vol.107, No.D23, 4699, doi:10.1029/002JD002119 (2002)

(16) Y. Baba and V.A. Rakov: "On the use of lumped sources in lightning return stroke models", J. Geophys. Res., Vol.110, No.D03101, doi:10.1029/2004JD005202 (2005)

(17) E.M. Thomson: "Exact expressions for electric and magnetic fields from a propagating lightning channel with arbitrary orientation", J. Geophys. Res. Vol.104, pp.22293-22300 (1999)

(18) R. Thottappillil, J. Schoene, and M.A. Uman: "Return stroke transmission line model for stroke speed near and equal that of light", Geophys. Res. Lett. Vol.28, No.18, pp.3593-3596 (2001)

(19) Y. Baba and V.A. Rakov: "Influences of the presence of a tall grounded strike object and an upward connecting leader on lightning currents and electromagnetic fields", IEEE Trans. Electromagn. Compat., Vol.49, No.4, pp.886-892 (2007)

(20) Y. Baba and V.A. Rakov: "Lightning electromagnetic environment in the presence of a tall grounded strike object", J. Geophys. Res., Vol.110, No.D9, D09108, doi:10.1029/2004JD5505 (2005)

21) Y. Baba and V.A. Rakov: "Lightning strikes to tall objects: currents inferred from far electromagnetic fields versus directly measured currents", Geophys. Res. Lett., Vol.34, No.19, doi:10.1029/2007GL030870 (2007)

(22) A. Mosaddeghi, D. Pavanello, F. Rachidi, and M. Rubinstein: "On the inversion of polarity of the electric field at very close range from a tower struck by lightning", J. Geophys. Res., Vol.112, No.D19, D19113, 10.1029/2006JD008350 (2007)

(23) V.A. Rakov: "Lightning return stroke speed", J. Lightning Res., Vol.1, pp.80-89 (2007)

(24) Y. Baba and V.A. Rakov: "On the mechanism of attenuation of current waves propagating along a vertical perfectly conducting wire above ground: application to lightning", IEEE Trans. Electromagn. Compat., Vol.47, No.3, pp.521-532 (2005)

(25) D.M. Jordan and M.A. Uman: "Variation in light intensity with height and time from subsequent lightning return strokes", J. Geophys. Res., Vol.88, No.C11, pp.6555-6562 (1983)

(26) D. Wang, N. Takagi, T. Watanabe, V.A. Rakov, M.A. Uman, K.J. Rambo, and M.V. Stapleton: "A comparison of channel-base currents and optical signals for rocket-triggered lightning strokes", Atmospheric Res., Vol.76, No.1-4, pp.412-422 (2005)

(27) V.A. Rakov and A.A. Dulzon: "Calculated electromagnetic fields of lightning return strokes”, Tek. Elektr., No.1, pp. 87-89 (1987) (in Russian)

(28) Y. Baba and M. Ishii: "Lightning return stroke model incorporating current distortion", IEEE Trans. Electromagn. Compat., Vol.44, No.3, pp.476-478 (2002)

29) G. Diendorfer and M.A. Uman: "An improved return stroke model with specified channel-base current", J. Geophys. Res., Vol.95, No. D9, pp.13621-13644 (1990)

30) F. Rachidi and C.A. Nucci: "On the Master, Lin, Uman, Standler and the modified transmission line lightning return stroke current model", J. Geophys. Res., Vol.95, pp.20389-20394 (1990)

(31) V. Cooray: "On the concepts used in return stroke models applied in engineering practice", IEEE Trans. Electromagn. Compat., Vol.45, No.1, pp.101-108 (2003)

(32) G. Diendorfer, W. Schulz, and F. Fuchs: "Comparison of correlated data from the Austrian lightning location system and measured lightning currents at the Peissenberg tower", Proc. 24th Int. Conf. Lightning Protection, Birmingham, U.K. (1998)

33) A. Lafkovici, A.M. Hussein, W. Janischewskyj, and K.L. Cummins: "Performance analysis of the north American lightning detection network using CN Tower lightning data", Proc. 19th Int. Lightning Detection Conf., Vaisala, Tucson, Arizona (2006)

(34) B.N. Gorin and A.V. Shkilev: "Measurements of lightning currents at the Ostankino tower", Electrichestrvo, No.8, pp.64-65 (1984) (in Russian)

(35) C.A. Balanis: Antenna Theory, Analysis and Design, 2nd. Ed., Wiley, New York (1997)

(36) F. Heidler and C. Hopf: "Lightning current and lightning electromagnetic impulse considering reflection at the earth's surface", Proc. 22nd Int. Conf Lightning Protection, Budapest, Hungary (1994)

(37) V. Shostak, W. Janischewskyj, A.M. Hussein, J.-S. Chang, and B. Kordi: "Return stroke current modeling of lightning striking a tall tower accounting for reflections within the growing channel and for upward-connecting discharges", Proc. Int. Conf. Atmospheric Electricity, Gunterville, AL (1999)

(38) S. Miyazaki and M. Ishii: "Reproduction of time derivative of electromagnetic field associated with rocket-triggered lightning in submicrosecond range", J. Geophys. Res., Vol.111, No.D22, D22203, 10.1029/2005JD006471 (2006)

(39) R. Thottappillil and N. Theethayi: "Realistic sources for modeling lightning attachment to towers", Proc. Int. Conf. Grounding and Earthing 2006, No.2, Maceio, Brazil (2006)

馬 場 吉 弘 (正員) 1971 年 2 月生。 1994 年 3 月東京大学工

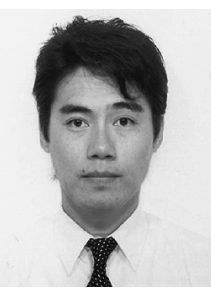
学部電気工学科卒業。1999 年 3 月同大学大学院 工学系研究科電気工学専攻博士課程修了。同年 4 月同志社大学助手, 2001 年 4 月同専任講師, 2005 年 4 月同助教授。 2007 年 4 月同准教授，現在に 至る。2003 年 4 月から 2004 年 8 月フロリダ大学 客員研究員。電磁界パルスに関する研究に従事。 博士 (工学)。1999 年電気学会論文賞受賞。 